\title{
DIFFERENCES IN CHEMICAL PARAMETERS OF COLD PRESSED OIL AND REFINED COOKING OIL
}

\author{
Gorica Pavlovska, Vezirka Jankuloska, Vesna Antoska Knighs, Elena Stojanova \\ Faculty of Technology and Technical Sciences, Veles, \\ University "St. Kliment Ohridski”, Bitola, Republic of Macedonia \\ gorica.pavlovska@uklo.edu.mk
}

\begin{abstract}
Cold pressed and refined oils vary in sensory properties, chemical composition and nutritional properties. Cold pressed oil is unrefined sunflower oil which has greater nutritional properties, but oxidizes much faster and at lower temperatures than refined oil. There were analyzed two sunflower oils: cold pressed sunflower oil "Fila" and refined sunflower oil "Kristal". Oils were analyzed in accordance to the Oils Rules and fats and oils quality. Iodine, peroxide and acid number in the two oil types were determined. Iodine and peroxide number were determined by ISO 3961: 1996 while the acid number was determined by ISO 660: 39, 2009. Iodine number of refined oil is 127 and it is higher than the iodine number of cold pressed oil which is 86 . Peroxide and acid number are indicators for the oil oxidation and they are almost five times higher in cold strained oil than in refined oil. Oils were analyzed in accordance to the Oils Rules and fats and oils quality.
\end{abstract}

Key words: cooking oil; cold pressed; refined oil; sunflower oil

\section{РАЗЛИКИ ВО ХЕМИСКИТЕ СВОЈСТВА НА ЛАДНО ЦЕДЕНО И РАФИНИРАНО МАСЛО ЗА ЈАДЕЊЕ}

\begin{abstract}
Ладно цеденото и рафинираното масло за јадење се разликуваат по сензорните својства, хемискиот состав и нутритивните својства. Ладно цеденото масло е нерафинирано масло за јадење и има поголеми нутритивни својства, но оксидира многу побрзо и на пониски температури од рафинираното масло. Анализирани се ладно цедено сончогледово масло „Фила“ и рафинирано сончогледово масло „Кристал“. Определени се јоден, пероксиден и киселински број во двата вида масло. Јодниот и пероксидниот број се определуваат по ISO 3961: 1996, а киселинскиот по ISO 660: 2009. Јодниот број на рафинираното масло изнесува 127 и тој е повисок од јодниот број на ладно цеденото масло кој е 86. Пероксидниот и киселинскиот број се показатели за оксидација на маслото и тие се речиси пет пати повисоки кај ладно цеденото отколку кај рафинираното масло. Анализираните масла се во согласност со Правилникот за масла и квалитет на масти и масла за јадење.
\end{abstract}

Клучни зборови: масло за јадење; ладно цедено; рафинирано масло; сончогледово масло

\section{INTRODUCTION}

Oils and fats have a high biological nutritional value. They carry essential ingredients which are necessary for the human body, such as certain essential fatty acids, tocopherols, phosphatides, carotenoids, and vitamins A, D, E and K [Dimić, 2000; Jamieson and Baughman, 1922; Talal et al., 2013; Tasan and Demirci, 2005].

The oil can be found in some fruits and the seeds in some plants like: sunflower, olive, sesame, pumpkin and few more. Sunflower oil is one of the most used consume oils. The first patent of sunflower used as a raw material for preparing the oil was developed in England in 1716 [Dimić, 2005]. The sunflower oil can be obtained by extraction or pressing. Oil obtained by extraction can not be used without refining. Refining process allows oil to have an appealing appearance to consumers, i.e. by this process unwanted odors, tastes, colors and sediment are removed. Operations and processes that are performed during the process of refining, on one hand remove unfavourable and unwanted ingredients of the oil, but on the other hand they 
remove helpful and favorable ingredients such as vitamins, phospholipids, sterols and others [Marijan, 1964]. Oil refining consists of the following processes: before refining, neutralization, bleaching, vinterization, deodorization and clarification [Dimić et al., 2003].

Cold pressed oil is unrefined oil and it differs from refined oil by sensory properties, chemical composition, nutritional properties and stability. Pressed or cold strained oil contains essential fatty acids and antioxidants: vitamin $\mathrm{E}$ and selenium [Butinar et al., 2011].

Cooking oils and oils that are part of other foods can oxidize in a more standing and a higher temperature [Monika et al., 2002; Wąsowicz et al., 2004]. The quality of oil is determined by several parameters: peroxide number, acid number, iodine number, etc. [Jankuloska and Pavlovska, 2015; Karlović and Andrić, 1996; Rehab, 2010; Zhang et al., 2010]. Peroxide number determines the amount of oxidation products in the oil. Acid number gives the amount of free fatty acids and the iodine number is a measure of identification of oil. These parameters are legally regulated by the Rulebook of fats and oils of Republic of Macedonia [Official Journal of R. Macedonia No.127, 2012].

To see what are the differences of these parameters in cold pressed and refined oil, and to prove if these oils meet the legal regulations in Macedonia, one sample of both types of oil was analyzed.

\section{MATERIALS AND METHODS}

Cold pressed sunflower oil "Fila" and refined sunflower oil "Kristal" are analyzed. Oil samples (total 20,10 of both) are taken from a bottle of 1 liter in 10 stores in Macedonia. Iodine number, peroxide number and acid number are certain of both types of oil.

The number of double bonds in the oil is determined with iodine number. It indicates identification that determines the type and origin of the oil. Iodine number is determined by the method ISO 3961: 1996.

Hydroperoxides and peroxides are the oxidation products in the oil. Their amount is determined by the peroxide number with method ISO 3961: 1996.

The presence of free fatty acids is determined by acid number method ISO 660: 2009.

In the analysis it is necessary to introduce some numerical measures that will support the graphic view. Such measure is the Pearson's correlation coefficient [Newbold et al., 2007; Levine et al., 2008].

Correlation measures the direction and strength of the linear relationship between two quantitative variables and is usually denoted by $r$. It represents an average value of the sum of the products of standardized values of two variables.

\section{RESULTS AND DISCUSSION}

Iodine number is a parameter which is legally regulated [Official Journal of R. Macedonia No. 127, 2012]. Average, standard deviation (sd) and variance $(\mathrm{cv})$ of both types of oil are given in Table 1. The obtained results of both types of oil are compared with the maximum allowable concentrations (MAC) for iodine value (Figure 1).

\section{Table 1}

Statistics for iodine number of refined and cold pressed sunflower oil

\begin{tabular}{ccc}
\hline \hline $\begin{array}{c}\text { Number of } \\
\text { samples }\end{array}$ & $\begin{array}{c}\text { Refined sunflower } \\
\text { oil "Kristal" }\end{array}$ & $\begin{array}{c}\text { Cold pressed } \\
\text { sunflower oil "Fila" }\end{array}$ \\
\hline 1 & 126 & 87 \\
2 & 126 & 87 \\
3 & 127 & 85 \\
4 & 129 & 86 \\
5 & 127 & 86 \\
6 & 127 & 86 \\
7 & 126 & 85 \\
8 & 127 & 88 \\
9 & 128 & 85 \\
10 & 127 & 85 \\
Average & 127 & 86 \\
Sd & 0.9428 & 1.0541 \\
Cv & 0.8888 & 1.1111 \\
\hline \hline
\end{tabular}

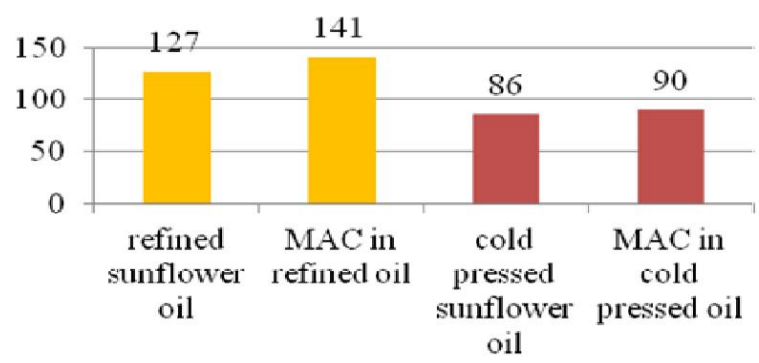

Fig. 1. Iodine number of refined and cold pressed sunflower oil 
The results show that iodine number in both oil types is very different. Iodine number of refined oil is 127 and is larger than the iodine number of unrefined oil which is 86 . This is because during the refining processes of neutralization and deodoration much of the free fatty acids were removed, while the process of vinterization removed saturated triglycerides. This means change of the composition of the oil and iodine number. Unrefined oil is not subject to the procedures of refining and therefore there is a lower iodine number.

Statistics for peroxide number in both types oil are given in Table 2.

\section{Table 2}

\section{Statistics for peroxide number of refined and cold} pressed sunflower oil

\begin{tabular}{ccc}
\hline $\begin{array}{c}\text { Number of } \\
\text { samples }\end{array}$ & $\begin{array}{c}\text { Refined sunflower } \\
\text { oil "Kristal" }\end{array}$ & $\begin{array}{c}\text { Cold pressed } \\
\text { sunflower oil "Fila" }\end{array}$ \\
\hline 1 & 1.35 & 6.20 \\
2 & 1.25 & 6.14 \\
3 & 1.31 & 6.30 \\
4 & 1.32 & 5.81 \\
5 & 1.24 & 5.72 \\
6 & 1.22 & 5.78 \\
7 & 1.26 & 6.01 \\
8 & 1.30 & 5.76 \\
9 & 1.25 & 5.83 \\
10 & 1.20 & 5.85 \\
average & 1.27 & 5.94 \\
Sd & 0.04784 & 0.20699 \\
Cv & 0.00229 & 0.04284 \\
\hline \hline
\end{tabular}

The results obtained of the peroxide number in both types of oil compared with the MAC are shown in Figure 2. Peroxide number of the virgin oil "Fila" is $5.94 \mathrm{mmol} / \mathrm{kg}$, while that of refined oil "Kristal" is lower and amounts to $1.27 \mathrm{mmol} / \mathrm{kg}$ because the refining process reduces the oxidation products. According to the Regulation on Quality of fats and oils, peroxide number in refined oils should amount to $5.00(\mathrm{mmol} / \mathrm{kg})$, and in the case for unrefined oils this value should be up to 7.50 $(\mathrm{mmol} / \mathrm{kg})$. It means that the oil is not oxidized and they are in accordance with the regulations.

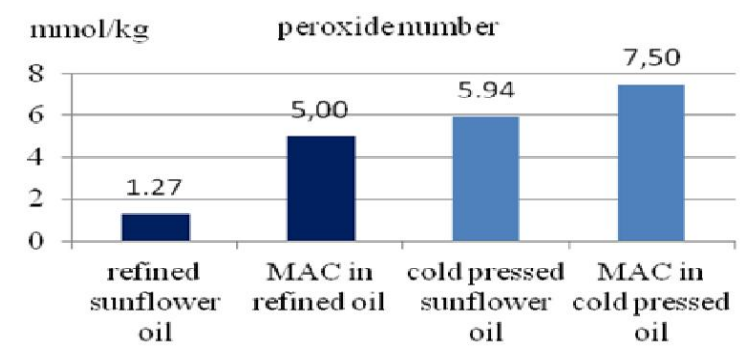

Fig. 2. Peroxide number of refined and cold pressed sunflower oil

Acid number is the last parameter specified in the analyzed oils. Because this parameter is prescribed by the regulations, the analyzed values are compared with the MAC for acid number (Table 3 and Figure 3).

Table 3

Statistics for acid number of refined
and cold pressed sunflower oil

\begin{tabular}{ccc}
\hline $\begin{array}{c}\text { Number of } \\
\text { samples }\end{array}$ & $\begin{array}{c}\text { Refined sunflower } \\
\text { oil "Kristal" }\end{array}$ & $\begin{array}{c}\text { Cold pressed } \\
\text { sunflower oil "Fila" }\end{array}$ \\
\hline 1 & 0.15 & 0.55 \\
2 & 0.16 & 0.57 \\
3 & 0.11 & 0.48 \\
4 & 0.14 & 0.47 \\
5 & 0.12 & 0.53 \\
6 & 0.15 & 0.53 \\
7 & 0.10 & 0.50 \\
8 & 0.12 & 0.48 \\
9 & 0.14 & 0.53 \\
10 & 0.11 & 0.56 \\
average & 0.13 & 0.52 \\
sd & 0.02055 & 0.03559 \\
cv & 0.00042 & 0.00127 \\
\hline \hline
\end{tabular}

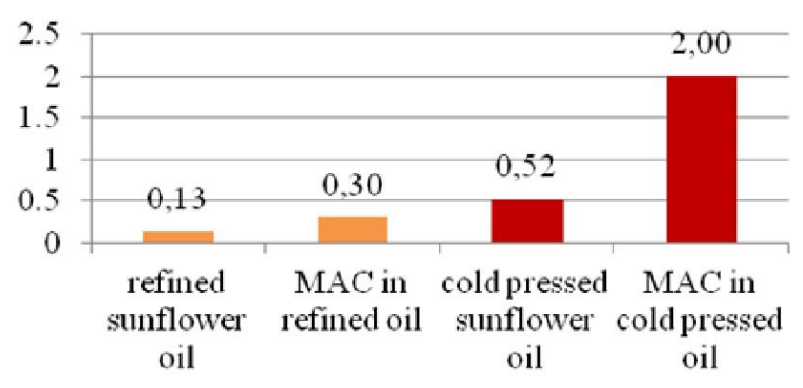

Fig. 3. Acid number of refined and cold pressed sunflower oil 
In refined sunflower oil substantial neutralization of free fatty acids was occurred and thus the acid number is only $0.13 \mathrm{~g} / \mathrm{kg}$. Unrefined oil "Fila" has a much higher acid number $0.52 \mathrm{~g} / \mathrm{kg}$, but it is several times lower than the MAC for unrefined oil. This means that cold extraction from sunflower seeds removed well the dirt and peels.

Coefficient of correlation of data for iodine number, peroxide number and acid number of refined and unrefined sunflower oil are calculated.

The calculated correlation coefficient was $r=0.99880$. It shows that the parameters obtained from the analysis of iodine number, peroxide number and acid number for refined oil are strongly correlated in terms of the parameters obtained for unrefined sunflower oil. Specifically this means that there is a strong linear mathematical relationship between the numerical parameters for iodine, peroxide and acid number of refined and appropriate numbers of unrefined sunflower oil.

\section{CONCLUSIONS}

Two oils, refined sunflower oil "Fila" and unrefined sunflower oil "Kristal" were analyzed and were obtained results of three important parameters for the oil: iodine number, peroxide number and acid number.

The refined oil has a higher iodine number than the crude oil because the process of refining removed the free fatty acids, waxes, triglycerides and others. Iodine number of both oil types is in accordance with the rules on fats and oils.

The analyzed oils have a peroxide number that varied among them. Peroxide number of the refined oil is much lower than that one of the unrefined oil. This is because during the process of refining were removed the oxidation products such as peroxides and hydroperoxides. The analyzed refined oil has four times lower peroxide number than the MAC value is, while the peroxide number of the analyzed unrefined oil is slightly lower than the MAC value for the unrefined oil.

The acid number of the analyzed oil is several times lower than the MAC for both oils. This means that refined and unrefined oils contain very little free fatty acids or the process of refining for the refined oil and the process of cold pressing for unrefined oil were successfully performed.

All three parameters which were analyzed in the both types of oil are lower than MAC which is prescribed by the regulators, what means that the oils are suitable for consumption.

\section{REFERENCES}

[1] Butinar, B., Bučar-Miklavčič, M., Mariani, C., Raspor, P.: New vitamin $\mathrm{E}$ isomers (gamma-tocomonoenol and alpha-tocomonoenol), in seeds, roasted seeds and roasted seed oil from the Slovenian pumpkin, variety 'Slovenska golica'. Food Chemistry, 128 (2), 505-512 (2011).

[2] Dimić, E.: Kontrola kvaliteta hladno presovanih ulja. Acta Periodica Technologica, 31A, 165-174(2000).

[3] Dimić, E.: Hladno ceđena ulja. Tehnološki fakultet, Novi Sad, 2005.

[4] Dimić, E., Tešanović, D., Romanić, R., Vukša, V.: Promene kvaliteta jestivih rafinisanih ulja suncokreta $\mathrm{u}$ periodu od 12 meseca. Uljarstvo, 34 (3-4), 1-7 (2003).

[5] Jankuloska, V., Pavlovska, G.: Obtaining refined sunflower eatable oil and quality control. Horizons, 11 (2), 29-39 (2015).

[6] Jamieson, J., Baughman, W.: The chemical composition of sunflower oil. Journal of the American Chemical Societies, 44 (12), 2952-2957 (1922).

[7] Karlović, D., Andrić, N.: Kontrola kvaliteta semena uljarica. Tehnoloski fakultet, Novi Sad, 264-274, 1996.

[8] Levine, D., Stephan, D., Krehbiel, T., Berenson, M.,: Statistics for Managers Using Microsoft Excel, Pearson Prentice-Hall, New Jersey, USA, 2008.

[9] Marijan, Rac: Ulja i masti. Poslovno udruzenje proizvođača biljnih ulja. Beograd, 1964.

[10] Hoffman Monika, Świderski Franciszek, Zalewski Stanislaw, Berger Stanislaw: Frying performance of rapeseedpalm oil, blends. Polish Journal of Food and Nutrition Sciences, Vol. 11/52, No. 1, pp 65-71 (2002).

[11] Newbold, P., Carlson, W., Thorne, B.: Statistic for Business and Economist. Pearson Education, Inc., New Jersey, USA, 2007.

[12] Official Journal of R. Macedonia: Rulebook on requirements regarding the quality of vegetable oils and vegetable fats, margarine, mayonnaise and related products. $\mathrm{R}$ Macedonia. No. 127 (2012).

[13] Rehab, F.M.A.: Improvement the stability of fried sunflower oil by using different levels of Pomposia (Syzyygium Cumini). Electronic Journal of Environmental, Agricultural and Food Chemistry, 9 (2), 396-403 (2010).

[14] Talal, E., Jiang, J., Yuanfa, L.: Chemical refining of sunflower oil: effect on oil stability, total tocopherol, free fatty acids and colour. International Journal of Engineering Science and Technology, 5 (2), 449-454 (2013).

[15] Tasan, M., Demirci, M.: Total and individual tocopherol contents of sunflower oil at different stepsofrefining. European Food Research and Technology, 220, 251-254 (2005).

[16] Wąsowicz, E., Gramza, A., Marzanna, H., Jelec, H., Korczak, J., Maiecka, M., Mildner-Szkudlarz, S., Rudzicska, R., Samotyja, U., Zawirska-Wojtasiak, R.: Oxidation of lipids in food. Polish Journal of Food and Nutrition Sciences, 13 (54), 87-100 (2004).

[17] Zhang, Y., Yang, L., Zu, Y., Chen, X., Wang, F., Liu, F.: Oxidative stability of sunflower oil by carnosic acid compared with synthetic antioxidants during accelerated storage. Food Chemistry, 118 (3), 656-662 (2010). 